\title{
Distribution and diversity of entomopathogenic nematodes (Steinernematidae and Heterorhabditidae) in a South African nature reserve
}

\begin{tabular}{|c|c|}
\hline \multicolumn{2}{|c|}{$\begin{array}{l}\text { Authors: } \\
\text { Isiah Nthenga }{ }^{1,2} \text { @ } \\
\text { Rinus Knoetze } \\
\text { Antoinette P. Malan }{ }^{3,4}\end{array}$} \\
\hline \multicolumn{2}{|c|}{$\begin{array}{l}\text { Affiliations: } \\
{ }^{1} \text { Faculty of AgriSciences, } \\
\text { Stellenbosch University, } \\
\text { Stellenbosch, South Africa }\end{array}$} \\
\hline \multicolumn{2}{|c|}{$\begin{array}{l}\text { 2Department of Biology, } \\
\text { Nematology Research Group, } \\
\text { Faculty of Biological Sciences, } \\
\text { Gent University, Gent, } \\
\text { Belgium }\end{array}$} \\
\hline \multicolumn{2}{|c|}{$\begin{array}{l}{ }^{3} \text { Department of Conservation } \\
\text { Ecology and Entomology, } \\
\text { Faculty of AgriSciences, } \\
\text { Stellenbosch University, } \\
\text { Stellenbosch, South Africa }\end{array}$} \\
\hline \multicolumn{2}{|c|}{$\begin{array}{l}\text { "Plant Protection Division, } \\
\text { Agricultural Research Council } \\
\text { (ARC), Stellenbosch, } \\
\text { South Africa }\end{array}$} \\
\hline \multicolumn{2}{|c|}{$\begin{array}{l}\text { Corresponding autho } \\
\text { Antoinette Malan, } \\
\text { apm@sun.ac.za }\end{array}$} \\
\hline \multicolumn{2}{|c|}{$\begin{array}{l}\text { Dates: } \\
\text { Received: } 30 \text { Oct. } 2020 \\
\text { Accepted: } 18 \text { Sept. } 2021 \\
\text { Published: } 22 \text { Nov. } 2021\end{array}$} \\
\hline \multicolumn{2}{|c|}{$\begin{array}{l}\text { How to cite this article: } \\
\text { Nthenga, I., Knoetze, R. \& } \\
\text { Malan, A.P., 2021, } \\
\text { 'Distribution and diversity } \\
\text { of entomopathogenic } \\
\text { nematodes } \\
\text { (Steinernematidae and } \\
\text { Heterorhabditidae) in a South } \\
\text { African nature reserve', } \\
\text { Koedoe 63(1), a1661. } \\
\text { https://doi.org/10.4102/ } \\
\text { koedoe.v63i1.1661 }\end{array}$} \\
\hline \multicolumn{2}{|l|}{ Read online: } \\
\hline 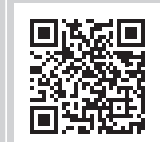 & $\begin{array}{l}\text { Scan this QR } \\
\text { code with your } \\
\text { smart phone or } \\
\text { mobile device } \\
\text { to read online. }\end{array}$ \\
\hline
\end{tabular}

Entomopathogenic nematodes (EPNs) are microscopic roundworms that are found in soil worldwide. They deliver an important ecosystem service through preventing natural flares in insect reproduction by means of utilising the soil stages of insects as a food source and by acting as natural biocontrol agents. A survey of EPNs was conducted in the JS Marais Nature Reserve, Stellenbosch, in the Western Cape province of South Africa. Soil samples were baited with the larvae of three susceptible hosts, codling moth (Cydia pomonella), wax moth (Galleria mellonella) and mealworm (Tenebrio molitor) to determine the presence of EPN. Of the 76 soil samples collected across the reserve, 39 were found to be positive for the presence of EPN $(51.32 \%)$. Among the positive samples, $87 \%$ contained Steinernema isolates, $8 \%$ contained Heterorhabditis and 5\% contained the Oscheius sp. Morphological and molecular studies were performed to characterise the isolates to species level. The Steinernema species were identified as Steinernema khoisanae in 34 samples, and as Steinernema nguyeni in five samples. The only species of Heterorhabditis found was H. safricana, which was identified from three samples. An unknown Oscheius sp. was found in two samples. The reserve's population of S. khoisanae showed interesting inter-individual variation (93\%) early in the internal transcribe spacer (ITS) region, leading to short single-usable sequences, which, in most cases, included only the ITS1 or ITS2 region. However, using the D2D3 confirmed their identity as S. khoisanae, with such occurring in all areas and soil types of the reserve.

Conservation implications: The undisturbed alluvial fynbos and renosterveld of the JS Marais Nature Reserve showed high EPN abundance and diversity in stark contrast to the agro-ecosystems present in the Cape floristic region. This finding, on a micro level, should be conserved for future bioprospecting in the fynbos for EPNs with potential as biocontrol agents.

Keywords: distribution; fynbos; JS Marais Nature Reserve; natural habitat; natural veld.

\section{Introduction}

Entomopathogenic nematodes (EPNs) in the families Steinernematidae and Heterorhabditidae are of great interest because of their potential as commercial biological control agents against insects. Entomopathogenic nematodes are lethal, obligate parasites of soil-dwelling stages of insect pests (Burnell \& Stock 2000). They occur naturally in all soils worldwide, with their control of the soil stages of insects acting as an ecosystem service for keeping insect populations at bay. Entomopathogenic nematodes have been successfully used worldwide as biological control agents to suppress over 200 economically important insect pests (Grewal, Ehlers \& Shapiro-Ilan 2006; Kaya \& Gaugler 1993; Shapiro-Ilan, Gouge \& Koppenhofer 2002).

Entomopathogenic nematode surveys during the last decades yielded an increasing number of new species. Entomopathogenic nematodes are found globally, except for Antarctica, where they have yet to be found (Griffin, Downes \& Block 1990; Hominick 2002). The study of natural EPN occurrence and distribution, as characterised by different ecological habitats in various geographical areas, provides baseline information for incorporating the pathogens in biological control programmes, and for understanding the complexities of their biodiversity. The factors such as geographical location, climatic conditions, soil properties and habitat type may determine the occurrence and distribution of the EPNs. To be effective as biological control agents, EPNs need to be adapted to the local environmental conditions of the site of application (Bedding 1990). However, with inundative application, with an immediate effect on the target organism, temperature and humidity are the most important environmental factors to take into consideration.

Copyright: ( 2021. The Authors. Licensee: AOSIS. This work is licensed under the Creative Commons Attribution License. 
In South Africa, five major surveys have been conducted to isolate EPNs for use as biological control agents (Hatting \& Malan 2017; Malan \& Hatting 2015). A survey was conducted between 2004 and 2005, during which 498 soil samples were collected, with only 36 representing $7 \%$ of the total number of samples testing positive for EPNs (Malan, Nguyen \& Addison 2006). This survey, aimed at obtaining EPNs for use as biological control agents against codling moth (Cydia pomonella Linnaeus), were restricted to the southern part of the Western Cape province. Another survey, aimed at determining the distribution and diversity of EPNs, was conducted between 2003 and 2005, during which 1508 soil samples were collected. This survey, in which only $79(5 \%)$ of the total samples tested positive for EPNs (Hatting, Stock \& Hazir 2009), was conducted in the Western Cape, Free State, Gauteng, Mpumalanga and KwaZulu-Natal provinces. The third survey, aimed at determining the potential of EPNs for the control of the soil stages of a false codling moth, Thaumatotibia leucotreta (Meyrick), consisted of 202 soil samples, of which $35(17 \%)$ were found to test positive for the presence of EPNs (Malan, Knoetze \& Moore 2011). Three provinces were targeted in the survey, namely the Western Cape, the Eastern Cape and Mpumalanga provinces. Recent surveys were conducted by Steyn et al. (2017b) from avocado, litchi and macadamia orchards in the subtropical regions of Mpumalanga, Limpopo and KwaZulu-Natal provinces, while Abate et al. (2018) surveyed Eucalyptus spp., Pinus spp. and Acacia mearnsii De Wild plantations in KwaZulu-Natal and Mpumalanga. Both surveys reported new Steinernema species, Steinernema fabii Abate, Malan, Tiedt, Wingfield, Slippers \& Hurley (Abate et al. 2016) and Steinernema litchi Steyn, Knoetze, Tiedt and Malan (Steyn et al. 2017a), as well as new reports for South Africa of Heterorhabditis taysearae Shamseldean, El-Sooud, Abd-Elgawad \& Saleh (Steyn et al. 2017b) and Heterorhabditis baujardi Phan, Subbotin, Nguyen and Moens (Abate et al. 2018; Steyn et al. 2017b). The above surveys have contributed to the existing knowledge of the geographical distribution and diversity of EPNs.

The natural vegetation type in the Western Cape consists of fynbos, with such vegetation consisting primarily of natural shrubland, which occurs in a small belt of the Western Cape, which has a Mediterranean climate, characterised by winter rainfall (Esler, Pierce \& De Villiers 2014). The fynbos biogeography is known for its exceptional degree of biodiversity and endemism. The diversity of fynbos plants is extremely high, with over 9000 species of plants occurring in the area, of which about 6200 are endemic. The extremely high level of diversity is comparable to that of tropical rainforests or large islands, and it is unique to the relatively dry African continent (Esler et al. 2014). It is hypothesised that the diversity of EPNs in the fynbos will be as diverse, as different vegetation types it is associated with.

The objective of the current study was to determine the distribution and composition of indigenous EPNs in the natural vegetation of the Western Cape province, in terms of the fynbos found in the JS Marais Nature Reserve in the town of Stellenbosch. The information obtained should add to the knowledge of the occurrence and distribution of EPNs in mostly undisturbed soils in South Africa.

\section{Materials and methods Study area}

The JS Marais Nature Reserve, which is composed of natural veld and managed areas, covers an area of 23 ha, situated on the eastern side of the Stellenbosch University campus, in the town of Stellenbosch, Western Cape. The area was proclaimed as a nature reserve in 2019. The natural veld is found in the A blocks, with the managed areas in blocks B, C and D (Figure 1). In the Western Cape, very little natural vegetation remains between the mountains and the sea, making the conservation of the two veld types very important. The reserve protects the original habitats of the alluvial terraces on which the town of Stellenbosch was established. The reserve contains the only remaining of Boland granite fynbos and Swartland renosterveld (Mucina \& Rutherford 2006). Alien vegetation found in the reserve includes Pinus radiata D., Pinus pinea L. and various Eucalyptus species.

The climatic data about the reserve, incorporating a longterm summary over a period of 33 years, were obtained from the ARC Infruitec-Nietvoorbij weather station at Nietvoorbij farm, being the closest weather station to the nature reserve. The reserve is in a winter rainfall region, with an average rainfall of between $700 \mathrm{~mm}$ and $1500 \mathrm{~mm}$. The maximum monthly temperature for a 33-year period was during November 1972 , with it being $41.2{ }^{\circ} \mathrm{C}$ and with the lowest minimum monthly temperature being $1.1^{\circ} \mathrm{C}$. The very low temperatures occurring in the reserve are frequently accompanied by snowfall on the mountain peaks surrounding Stellenbosch.

The general surface layer of the JS Marais Nature Reserve consists of loose gravel, with a highly variable sand matrix. The soil of the reserve is largely Eerste River alluvial gravel, which is derived from Table Mountain sandstone and some granite.

\section{Collection of soil samples}

The reserve is demarcated into 22 block sections (Figure 1), with each block being chosen as a sampling site. A total of 76 soil samples were collected in the reserve during August and September of 2012. At each sampling site, in an area of approximately $50 \mathrm{~m}^{2}$, five subsamples, consisting of approximately $200 \mathrm{~g}$ of soil, were taken at least $4 \mathrm{~m}$ apart, in a cross-sampling design and at a depth of $10-15 \mathrm{~cm}$, using a small hand trowel. The subsamples from each site were combined into a single plastic bag and mixed thoroughly. Between samples, the shovel was thoroughly cleaned with water and dried with paper towels, to prevent contamination between the next sampling site. Approximately $500 \mathrm{~g}$ of the soil from each sample was placed in polyethylene bags to prevent loss of moisture, whereupon the bags were labelled and taken to the laboratory for processing. The following 


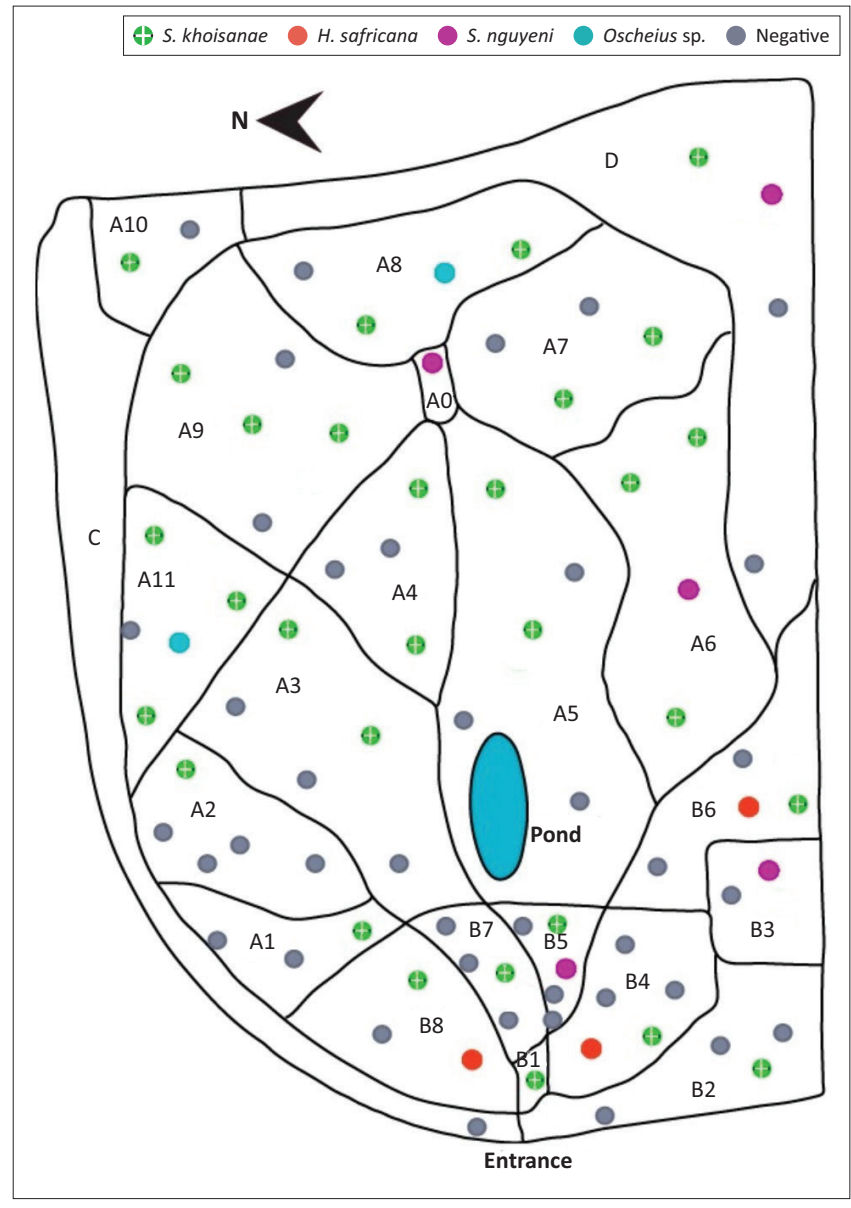

FIGURE 1: Map showing sites where samples were taken, indicating the positive and negative sampling sites and the different species of entomopathogenic nematodes isolated.

information was recorded: the site location, the date, the global positioning system (GPS) reading and the vegetation and soil type.

\section{Source of insect hosts}

The greater wax moth, Galleria mellonella (Linnaeus) (Lepidoptera: Phylaridae), was cultured in a growth medium and maintained at $25^{\circ} \mathrm{C}$. It is the most frequently used insect for the propagation of EPNs, because it is easy to maintain and very susceptible to EPNs. Mealworm, Tenebrio molitor (Linnaeus) (Coleoptera: Tenebrionidae) larvae were cultured, using bran, with carrots for moisture (Van Zyl \& Malan 2015). The culture was maintained at room temperature. Codling moth, Cydia pomonella (Linnaeus) larvae, which were kept at $4{ }^{\circ} \mathrm{C}$, were obtained from the Entomon facility at Welgevallen Experimental Farm.

\section{Isolation of nematodes}

Entomopathogenic nematodes were recovered from the soil samples, using an insect-baiting method described by Bedding and Akhurst (1975). In the laboratory, soil samples from each site were placed into $500 \mathrm{~mL}$ plastic containers. Five last instars each of wax moth larvae, mealworm larvae and codling moth larvae were added to each soil sample and stored at room temperature of $20 \pm 22{ }^{\circ} \mathrm{C}$ for 21 days. The soil traps were checked every 7 days and dead larvae removed from the pots and replaced with healthy ones. The dead insects from each sample were rinsed in water and placed in a $9 \mathrm{~cm}$ Petri dish lined with moist filter paper for 5-6 days. The larvae showing signs of EPN attack were transferred to a modified white trap (Kaya \& Stock 1997; Woodring \& Kaya 1988) to collect the infective juveniles (IJs).

To verify the pathogenicity of collected nematodes and to establish new cultures, the emerging nematodes were collected for each sample and used to infect fresh G. mellonella larvae. Parasitised G. mellonella were placed on a white trap to collect the IJs, which were then stored in culture flasks at $14^{\circ} \mathrm{C}$ in water.

\section{Molecular characterisation}

The molecular approach in identifying the nematodes was according to Nguyen and Smart (1996) and Nguyen, Maruniak and Adams (2001). DNA was extracted from a single nematode female, using a modification of a method reported by Nguyen (2007). The ITS-rDNA regions were amplified using the ITS primers 18S: 5'-TTGATTACGTCCCTGCCCTTT-3' (forward) and 26S: 5'-TTTCACTCGCCGTTACTAAGG-3' (reverse) as reported by Vrain et al. (1992). The forward primer D2F: 5'-CCTTAGTAACGGCGAGTGAAA-3' (Nguyen, Malan \& Gozel 2006) and the reverse primer 536: 5'-CAGCTATCCTGACCAAAC- (Stock, Pryor \& Kaya 1999) were used to amplify the D2-D3 expansion segments of $28 \mathrm{~S}$ rRNA. Polymerase chain reaction (PCR) products were cleaned up and sequenced by the Central Analytical Facilities (CAF) of the Stellenbosch University. The sequence was assembled and edited using the CLC DNA Workbench (http://www.clcbio.com). The sequences generated of the ITS region of all the positive samples were compared with those of the species made available on GenBank (NCBI).

\section{Morphological and morphometric characterisation}

To determine the genus of the isolated EPNs, the diagnostic criteria suggested by Stock and Kaya (1996) were used. Microscopic examination of live IJs, males and females was performed to support the molecular identity of the different isolates, using key diagnostic features (Nguyen \& Smart 1996). Measurements were made by means of a Leica DM2000 compound microscope (Leica Microsystems, Wetzlar, Germany), fitted with a digital camera and with software Leica Application Suite V3.5.0.

\section{Results}

More than half (39) of the samples collected the nature reserve contained EPNs. Two endemic species of Steinernema (29 isolates) were isolated and identified with molecular techniques viz. Steinernema khoisanae (24 isolates) and Steinernema nguyeni Malan, Knoetze and Tiedt (five isolates). Heterorhabditis safricana Malan, Nguyen, De Waal and 
TABLE 1: Identification of entomopathogenic nematodes (Steinernema, Heterorhabditis and Oscheius) isolated from soil collected at the JS Marais Nature Reserve.

\begin{tabular}{|c|c|c|c|c|c|c|c|c|c|c|c|c|c|}
\hline \multirow[t]{2}{*}{ Species } & \multirow[t]{2}{*}{ Strain } & \multirow{2}{*}{$\begin{array}{l}\text { GenBank } \\
\text { number } \\
\text { ITS }\end{array}$} & \multirow{2}{*}{$\begin{array}{l}\text { Base } \\
\text { pairs }\end{array}$} & \multirow[t]{2}{*}{ Primer } & \multirow{2}{*}{$\begin{array}{l}\text { GenBank } \\
\text { D2D3† }\end{array}$} & \multirow{2}{*}{$\begin{array}{l}\text { Base } \\
\text { pairs }\end{array}$} & \multicolumn{2}{|c|}{ Map area Longitude } & \multirow[t]{2}{*}{ Latitude } & \multirow[t]{2}{*}{ Altitude } & \multicolumn{3}{|c|}{ Trapping host } \\
\hline & & & & & & & & & & & $\mathrm{CM}$ & MW & WM \\
\hline S. khoisanae & $1-7$ & MT872060 & 588 & $18 S / 26 S$ & - & - & $A 6$ & S33 $56^{\prime} .034^{\prime \prime}$ & E18 $52^{\prime} .528^{\prime \prime}$ & 141 & - & $x$ & $x$ \\
\hline S. khoisanae & $\mathrm{I}-10$ & MT863746 & 407 & $18 S / 26 S$ & MT899478 & 889 & A9 & $\mathrm{S} 33^{\circ} 55^{\prime} .833^{\prime \prime}$ & E18 $52^{\prime} .699^{\prime \prime}$ & 85 & $x$ & $x$ & $x$ \\
\hline Oscheius sp. & $\mathrm{I}-12$ & KX068706 & 1020 & $18 S / 26 S$ & - & - & A11 & $\mathrm{S} 33^{\circ} 55^{\prime} .864^{\prime \prime}$ & $\mathrm{E} 18^{\circ} 52^{\prime} .577^{\prime \prime}$ & 141 & - & $x$ & - \\
\hline S. khoisanae & $\mathrm{I}-13$ & MT872084 & 342 & $18 S / 26 S$ & MT899479 & 881 & B1 & S335'.992' & E18 $52^{\prime} .404^{\prime \prime}$ & 117 & - & $x$ & - \\
\hline S. nguyeni & $\mathrm{I}-15$ & MT680196 & 967 & - & - & - & B3 & $\mathrm{S} 33^{\circ} 56^{\prime} .039^{\prime \prime}$ & E18 $52^{\prime} .412^{\prime \prime}$ & 137 & - & $x$ & - \\
\hline S. khoisanae & $\mathrm{I}-17$ & MT875263 & 234 & $18 S / 26 S$ & MT899480 & 881 & B4 & S $33^{\circ} 56^{\prime} .006^{\prime \prime}$ & E18 $52^{\prime} .406^{\prime \prime}$ & 133 & - & $x$ & $x$ \\
\hline S. khoisanae & $\mathrm{I}-20$ & MT861056 & 626 & $18 S / 26 S$ & - & - & B6 & $\mathrm{S} 33^{\circ} 56^{\prime} .061^{\prime \prime}$ & $\mathrm{E} 18^{\circ} 52^{\prime} .465^{\prime \prime}$ & 134 & - & $x$ & - \\
\hline S. khoisanae & $\mathrm{I}-24$ & MT900432 & 499 & $18 \mathrm{~S} / 26 \mathrm{~S}$ & - & - & B8 & S33 $55^{\prime} .942^{\prime \prime}$ & $\mathrm{E} 18^{\circ} 52^{\prime} .428^{\prime \prime}$ & 114 & - & $x$ & $x$ \\
\hline S. nguyeni & $\mathrm{I}-27$ & MT702994 & 976 & $18 S / 26 S$ & - & - & $A 6$ & S33 $55^{\prime} .053^{\prime \prime}$ & E18 $52^{\circ} .586^{\prime \prime}$ & 110 & - & $x$ & - \\
\hline S. nguyeni & $\mathrm{I}-28$ & MT702995 & 973 & $18 \mathrm{~S} / 26 \mathrm{~S}$ & - & - & A0 & S33 $55^{\prime} .955^{\prime \prime}$ & $\mathrm{E} 18^{\circ} 52^{\prime} .622^{\prime \prime}$ & 141 & $x$ & $x$ & - \\
\hline S. khoisanae & $1-29$ & MT9008331 & 229 & $18 S / 26 S$ & MT899481 & 884 & B7 & S33 $55^{\prime} .984^{\prime \prime}$ & E18 $52^{\prime} .423^{\prime \prime}$ & 134 & $x$ & $x$ & - \\
\hline S. khoisanae & $1-31$ & MT892935 & 672 & $18 S / 26 S$ & MT899482 & 884 & A5 & $\mathrm{S} 33^{\circ} 55^{\prime} .961^{\prime \prime}$ & E18 $52^{\circ} .555^{\prime \prime}$ & 129 & - & $x$ & - \\
\hline S. khoisanae & $1-33$ & МT921672 & 276 & $18 S / 26 S$ & MT899484 & 884 & A9 & S335'.936" & $\mathrm{E} 18^{\circ} 52^{\prime} .656^{\prime \prime}$ & 132 & - & - & $x$ \\
\hline S. khoisanae & $1-34$ & МT950347 & 235 & $18 S / 26 S$ & MT899485 & 884 & A8 & S33 $55^{\prime} .925^{\prime \prime}$ & E18 $52^{\prime} .680^{\prime \prime}$ & 134 & - & $x$ & - \\
\hline S. khoisanae & $1-36$ & MW111543 & 234 & TW81/AB28 & - & - & $\mathrm{A} 10$ & $\mathrm{~S} 33^{\circ} 55^{\prime} .850^{\prime \prime}$ & E18 $52^{\prime} .685^{\prime \prime}$ & 137 & - & $x$ & - \\
\hline S. khoisanae & $1-37$ & МT936508 & 707 & $18 S / 26 S$ & MT899486 & 884 & A9 & $\mathrm{S} 33^{\circ} 55^{\prime} .859^{\prime \prime}$ & $\mathrm{E} 18^{\circ} 52^{\prime} .645^{\prime \prime}$ & 136 & - & $x$ & - \\
\hline S. khoisanae & $1-38$ & МT940576 & 295 & $18 S / 26 S$ & МT899487 & 884 & A11 & $\mathrm{S} 33^{\circ} 55^{\prime} .865^{\prime \prime}$ & $\mathrm{E} 18^{\circ} 52^{\prime} .606^{\prime \prime}$ & 136 & $x$ & $x$ & $x$ \\
\hline S. khoisanae & $\mathrm{I}-40$ & МT936510 & 533 & TW81/AB28 & MT899488 & 884 & A11 & S335'.899” & E18 $52^{\prime} .584^{\prime \prime}$ & 137 & $x$ & $x$ & - \\
\hline S. khoisanae & $\mathrm{I}-41$ & MT940654 & 329 & $18 S / 26 S$ & MT899489 & 878 & A4 & $\mathrm{S} 33^{\circ} 55^{\prime} .949^{\prime \prime}$ & $\mathrm{E} 18^{\circ} 52^{\prime} .545^{\prime \prime}$ & 128 & $x$ & $x$ & - \\
\hline S. khoisanae & $\mathrm{I}-43$ & МT947073 & 238 & $18 S / 26 S$ & МT899490 & 876 & A3 & S33 $55^{\prime} .910^{\prime \prime}$ & E18 $52^{\prime} .556^{\prime \prime}$ & 121 & $x$ & $x$ & - \\
\hline S. khoisanae & $\mathrm{I}-45$ & MT950272 & 392 & $18 S / 26 S$ & MT899491 & 884 & D & S $33^{\circ} 56^{\prime} .033^{\prime \prime}$ & E $18^{\circ} 52^{\prime} .772^{\prime \prime}$ & 134 & $x$ & $x$ & - \\
\hline S. khoisanae & $\mathrm{I}-46$ & MT950273 & 534 & $18 S / 26 S$ & MT899492 & 884 & A7 & S $33^{\circ} 56^{\prime} .020^{\prime \prime}$ & E $18^{\circ} 52^{\prime} .675^{\prime \prime}$ & 133 & $x$ & $x$ & - \\
\hline S. khoisanae & $\mathrm{I}-47$ & MT974008 & 316 & $18 \mathrm{~S} / 26 \mathrm{~S}$ & MT899483 & 880 & A6 & S $33^{\circ} 55^{\prime} .008^{\prime \prime}$ & E $18^{\circ} 52^{\prime} 639^{\prime \prime}$ & 132 & - & $x$ & - \\
\hline S. khoisanae & $\mathrm{I}-48$ & MT974027 & 242 & $18 S / 26 \mathrm{~S}$ & MT899484 & 880 & A7 & S $33^{\circ} 55^{\prime} .990^{\prime \prime}$ & E $18^{\circ} 52^{\prime} 651^{\prime \prime}$ & 133 & - & $x$ & $x$ \\
\hline S. khoisanae & $\mathrm{I}-49$ & MT974092 & 476 & $18 \mathrm{~S} / 26 \mathrm{~S}$ & MT899485 & 880 & A6 & S $33^{\circ} 55^{\prime} .046^{\prime \prime}$ & E $18^{\circ} 52^{\prime} .664^{\prime \prime}$ & 137 & $x$ & $x$ & - \\
\hline S. nguyeni & $1-50$ & MT940450 & 958 & $18 S / 26 S$ & - & - & D3 & S33 $56^{\prime} .046^{\prime \prime}$ & E18 $52^{\prime} .772^{\prime \prime}$ & 139 & $x$ & $x$ & - \\
\hline Oscheius sp. & $\mid-51$ & MT702996 & 1038 & $18 S / 26 S$ & - & - & A8 & $\mathrm{S} 33^{\circ} 55^{\prime} .006^{\prime \prime}$ & $\mathrm{E} 18^{\circ} 52^{\prime} .756^{\prime \prime}$ & 138 & - & $x$ & - \\
\hline S. khoisanae & $1-60$ & МT957900 & 268 & $18 S / 26 S$ & MT899497 & 880 & A11 & S33 $55^{\prime} .862^{\prime \prime}$ & E18 $52^{\circ} .540^{\prime \prime}$ & 140 & - & $x$ & - \\
\hline S. khoisanae & I-61 & - & - & $18 S / 26 S$ & MT899498 & 881 & A3 & S33 $55^{\prime} .907^{\prime \prime}$ & E18 $52^{\prime} .507^{\prime \prime}$ & 138 & - & $x$ & - \\
\hline S. khoisanae & $1-62$ & МT974093 & 234 & $18 S / 26 S$ & MT899499 & 884 & A2 & S335'.916" & E18 $52^{\prime} .493^{\prime \prime}$ & 138 & - & $x$ & $x$ \\
\hline S. nguyeni & $1-65$ & MT702997 & 974 & $18 S / 26 S$ & - & - & B5 & S33 $56^{\prime} .995^{\prime \prime}$ & $\mathrm{E} 18^{\circ} 52^{\prime} .436^{\prime \prime}$ & 122 & - & $x$ & $x$ \\
\hline S. khoisanae & $1-67$ & - & - & $18 S / 26 S$ & MT899500 & 878 & B5 & $\mathrm{S} 33^{\circ} 56^{\prime} .000^{\prime \prime}$ & E18 $52^{\circ} .446^{\prime \prime}$ & 122 & - & - & $x$ \\
\hline S. khoisanae & $1-69$ & МT940648 & 731 & TW81/AB28 & - & - & A5 & $\mathrm{S} 33^{\circ} 56^{\prime} .000^{\prime \prime}$ & E18 $52^{\circ} .484^{\prime \prime}$ & 127 & - & $x$ & $x$ \\
\hline H. safricana & $1-71$ & - & - & TW81/AB28 & MT889743 & 848 & B4 & $\mathrm{S} 33^{\circ} 56^{\prime} .031^{\prime \prime}$ & E18 $52^{\prime} .457^{\prime \prime}$ & 130 & - & $x$ & $x$ \\
\hline H. safricana & $1-73$ & MW092902 & - & TW81/AB28 & - & - & B6 & $\mathrm{S} 33^{\circ} 56^{\prime} .047^{\prime \prime}$ & $\mathrm{E} 18^{\circ} 52^{\prime} .476^{\prime \prime}$ & 129 & - & $x$ & - \\
\hline H. safricana & $1-76$ & MT702998 & 889 & $28 S / 26 S$ & - & - & B8 & S $3^{\circ} 55^{\prime} .969^{\prime \prime}$ & $\mathrm{E} 18^{\circ} 52^{\prime} .413^{\prime \prime}$ & 129 & - & $x$ & $x$ \\
\hline
\end{tabular}

Note: Total number of host infected are trapping host $(\mathrm{CM})=11$, trapping host $(\mathrm{MW})=37$ and trapping host $(\mathrm{WM})=14$.

$\mathrm{CM}$, codling moth; MW, mealworm, WM, wax moth.

$\dagger, \mathrm{D} 2 \mathrm{~F} / 536$ primers.

Tiedt (Malan et al. 2008), the only Heterorhabditis found, was isolated from two samples. An unknown Oscheius sp. was also isolated from two soil samples (Table 1).

Sequences of the ITS region of S. khoisanae generated with the two primer pairs, TW81 (F) and AB28 (R) and 18S (F) and 26S (R), did not produce good-quality sequences. Only partial sequences of either the ITS1 with the forward primer, or ITS2 with the reverse primer, could be submitted to GenBank. Only in two cases was a full ITS (ITS1-2.8S-ITS2) region for S. khoisanae was obtained. However, sequencing of the D2-D3 regions of the $28 S$ gene large subunit produced goodquality sequencing $>880$ base pairs and confirmed their identity $(100 \%)$ with the isolates of populations of S. khoisanae (Table 1) reported from other areas in the Western Cape province.
All species isolated were trapped using mealworm, except at two samples, where S. khoisanae was trapped with wax moth. In 11 samples, both the mealworm and the codling moth trapped both S. khoisanae and S. nguyeni. Entomopathogenic nematodes were trapped in 14 samples using wax moth. In two samples, EPNs were trapped with all three trapping hosts, whereas, in 10 samples, both wax moth and mealworm trapped EPNs (Figure 1). The Oscheius sp. was trapped using mealworm (Table 1). The soil analysis showed that S. khoisanae were found in all the soil types throughout the nature reserve (Table 2).

Of all the isolates, the body length of 10 IJs was measured to confirm the molecular identification. The body length of S. khoisanae specimens from the JS Marais Nature Reserve was found to be slightly shorter than those of the type 
specimens 1010 (916-1127) $\mu \mathrm{m}$ versus 1062 (904-1159) $\mu \mathrm{m}$. In the case of $S$. nguyeni, the body length of the IJ correlated with that of the type specimen. For $H$. safricana, the IJ body length of the type specimen 697 (656-725) $\mu \mathrm{m}$ was found to be slightly longer, versus 600 (550-676) $\mu \mathrm{m}$ of the specimens found in this study. The sequences derived from the Oscheius sp. could not be matched to any known sequences in GenBank (Table 3); thus, possibly, it is a new, undescribed species of the genus.

\section{Discussion}

The occurrence and diversity of the EPNs found in the JS Marais Nature Reserve were high (51\%), with four species being identified, namely S. khoisanae, S. nguyeni, H. safricana and an Oscheius sp. The Steinernema spp. were more abundant than the others, which is found in $94 \%$ of the positive samples. Steinernema khoisanae was the most common species, which is found in $86 \%$ of the positive samples, with it being distributed all over the nature reserve. Of the positive soil samples, three contained S. nguyeni, three $H$. safricana and two with an unknown Oscheius sp. All four species are endemic to South Africa. The trend of more steinernematids being recovered than heterorhabditis as stated by Hominick (2002) was confirmed in the current survey.

In previous surveys undertaken to test for the presence of EPNs, the recovery rate was, in general, very low. A nontargeted survey by Malan et al. (2006) showed a 7\% recovery rate, while, in a targeted citrus orchard survey, $17 \%$ recovery was obtained for a total of 119 sampling sites. Hatting et al. (2009) undertook a comprehensive survey (of 1500 samples), with a very low recovery rate of $5 \%$. Most of these samples

TABLE 2: Representative soil samples analysed using a three-fraction soil analysis to indicate percentages differences in the different sampling regions.

\begin{tabular}{lccccccl}
\hline Area & Clay & Silt & $\begin{array}{c}\text { Fine } \\
\text { sand }\end{array}$ & $\begin{array}{c}\text { Medium } \\
\text { sand }\end{array}$ & $\begin{array}{c}\text { Coarse } \\
\text { sand }\end{array}$ & Classification Species \\
\hline A1 & 7 & 10 & 35 & 33 & 15 & LmSa & S. khoisanae \\
A2 & 7 & 10 & 35 & 29 & 18 & LmSa & S. khoisanae \\
A3-5 & 17 & 18 & 31 & 18 & 15 & SaLm & S. khoisanae \\
A6 & 5 & 8 & 19 & 31 & 36 & LmSa & S. khoisanae; S. nguyeni \\
A7 & 11 & 22 & 40 & 19 & 8 & SaLm & S. khoisanae \\
A8 & 7 & 16 & 30 & 29 & 17 & LmSa & S. khoisanae; Oscheius sp. \\
A9 & 7 & 16 & 34 & 27 & 16 & LmSa & S. khoisanae \\
A10 & 13 & 16 & 39 & 21 & 11 & SaLm & S. khoisanae \\
A11 & 23 & 32 & 31 & 10 & 4 & Lm & S. khoisanae; Oscheius sp. \\
B1 & 9 & 14 & 37 & 24 & 15 & LmSa & S. khoisanae \\
B3 & 11 & 16 & 39 & 24 & 9 & SaLm & S. nguyeni \\
B8 & 11 & 14 & 40 & 24 & 11 & SaLm & S. khoisanae; H. safricana \\
\hline
\end{tabular}

Sa, sand; Lm, lime. were taken from agricultural soil, which could be the reason for the low recovery rate obtained. In the current survey, less than four samples were collected per hectare, which is not regarded as intensive, as in orchards, 1 ha is usually divided into four quadrants, from which five subsamples are combined to give one sample, with a total of four samples per hectare (Steyn, Malan \& Addison 2020). From the information obtained, it can be extrapolated that the occurrence of EPNs in the JS Marais Nature Reserve was exceptionally high.

Three susceptible hosts were chosen for the isolation of EPNs because some species or strains could prove to be host-specific (Malan et al. 2011). During the present study, the most effective trapping host was T. molitor, from which all positive samples were trapped, except for two species of S. khoisanae, which were isolated with wax moth larvae. Unfortunately, the natural insect host of none of the EPN species isolated are known (Table 1). Some EPN species were found to be highly specific, like Steinernema scapterisci Nguyen and Smart, which appears to reproduce only in adult mole crickets (Scapteriscus spp.) (Nguyen \& Smart 1990). This indicates that many more EPNs might have been present in the soil but were not trapped by the three hosts used. Steinernema bertusi Katumanyane, Malan, Tiedt, Hurley, a newly described species for South Africa, was successfully isolated using wax moth and mealworm on two separate occasions and at two separate locations, from the KwaZulu-Natal and Mpumalanga provinces (Katumanyane et al. 2020).

The high abundance of S. khoisanae in the Western Cape province could suggest the presence of a wide range of suitable endemic hosts and favourable conditions for the species, which might contribute to its high observed frequency (Hatting et al. 2009; Malan et al. 2006, 2011). From the soil analysis (Table 2), S. khoisanae was noted to be present in all the soil types (LmSa, SaLm, Lm) of the nature reserve.

Intra-individual variability of the ITS region of most of the S. khoisanae individuals influenced the ability of standard primer pairs to produce high-quality sequences for this region that could successfully be aligned to identify the species. However, in this study, only two sequences were obtained by means of aligning the forward and the reverse sequences, both using the $28 \mathrm{~S}$ and $26 \mathrm{~S}$ primer pairs (Table 1 ). Using the D2D3 region of the $28 \mathrm{~S}$ gene region, high-quality sequences were obtained with both the forward and the reverse primers, thus confirming their identity as S. khoisanae. The ITS region, which is among the most important molecular

TABLE 3: Measurements of the body length of the infective juveniles.

\begin{tabular}{|c|c|c|c|c|c|c|}
\hline \multirow[t]{3}{*}{ Species } & \multirow[t]{3}{*}{ Number of isolates } & \multicolumn{4}{|c|}{ Mean (range) $\mu \mathrm{m}$ - Infective juvenile body length } & \multirow[t]{3}{*}{ Reference } \\
\hline & & \multicolumn{2}{|c|}{ Present study } & \multicolumn{2}{|c|}{ Type specimen } & \\
\hline & & Mean & Range & Mean & Range & \\
\hline Steinernema khoisanae & 25 & 1010 & $916-1127$ & 1062 & $904-1159$ & Nguyen et al. 2006 \\
\hline Steinernema nguyeni & 5 & 736 & $625-810$ & 737 & $673-796$ & Malan et al. 2016 \\
\hline Heterorhabditis safricana & 2 & 697 & $656-725$ & 600 & $550-676$ & Malan et al. 2008 \\
\hline Oscheius sp. & 3 & 603 & $519-655$ & - & & - \\
\hline
\end{tabular}

Note: $n=10$ infective juveniles of each isolate. 
markers used in identification, taxonomy and phylogeny of EPNs, was used with for the species identified from South Africa, as well as from other parts of the world (Malan \& Hatting 2015). Půža et al. (2015) found that, in Steinernema feltiae (Filipjev) Wouts, Mráček, Gerdin \& Bedding, intraindividual variability was found in $65 \%$ of specimens, and in almost $90 \%$ of the glaseri group, sampled from different localities. However, in the JS Marais Nature Reserve, $93 \%$ of the individuals in the population showed intra-individual variation early in the process of sequencing the ITS region, with the generation of short sequences at the $3^{\prime}$ and $5^{\prime}$ ends, which could not be aligned. Pǔža et al. (2015) also suggested the importance of using the D2D3 region to confirm the new species status of an EPN isolate. In this case, the D2D3 was used to confirm the species identification of most of the populations found in the same area, which is very rare occurrence.

De Waal et al. (2010) tested the virulence of six EPN species against diapausing codling moth, an insect of agricultural importance. The results showed the high susceptibility of codling moth for S. khoisanae, causing $97 \%$ and $88 \%$ infection, respectively. During a field trail against the false codling moth in citrus, $S$. khoisanae did not perform as well as did the other species tested. As the IJ of S. khoisanae is relatively large $(\approx 1 \mathrm{~cm})$, it generally cannot be used as a biocontrol against such micro insects as Bradysia impatiens and Frankliniella occidentalis (Pergande) (Thysanoptera: Thripidae) (Dlamini, Allsopp \& Malan 2019; Katumanyane, Ferreira \& Malan 2018). This specific population of S. khoisanae from the JS Marais Nature Reserve with its different ITS region should be tested against pest insects to compare it to other S. khoisanae populations with a normal ITS profile.

Steinernema nguyeni was first isolated from soil collected from beneath Olea europaea subsp. africana L. (Miller), an indigenous tree, near Clanwilliam in the Western Cape. The nematode was trapped using both G. mellonella and T. molitor. Similarly, it was reported from a survey conducted by De Waal, Malan and Addison (2011), as being isolated from undisturbed soil in the Knysna area of the Western Cape, but not in any other surveys.

Heterorhabditis safricana (SF281), which was described from a peach orchard in the Western Cape, has been isolated by trapping, using Galleria as host. It seems to be a rare species in South Africa, as previous surveys have detected its presence only in a peach orchard (Malan et al. 2008). Just two isolates were recovered during the current survey. Some controversy surrounds the status of the Oscheius (= Heterorhabditidoides) in its role as an entomopathogen, but the species found in the JS Marais Nature Reserve could most probably be a new species.

In terms of the recovery rate and frequencies reported by previous surveys, caution must be taken because of the differences in the sampling design, the time of sampling and the insect bait used. The high number of positive samples observed in the current survey may be attributed to the use of three different trapping hosts, and the increased number of sampling sites for the area to compensate for the patchy distribution of EPNs, as reported by Stock et al. (1999). The use of different insect hosts has shown that some isolates prefer certain hosts, which may lead to an underestimation of the natural occurrence of EPNs. However, the current study confirms that the use of mealworms is very effective for the isolation of species.

The present study provides an understanding of the distribution and diversity of the EPNs found in the JS Marais Nature Reserve, which is a natural ecosystem surrounded by urban development, which has remained undisturbed for over a century, in the heart Stellenbosch, in the Western Cape province. The unique intraspecific variation found in the ITS region of the $S$. khoisanae populations of the JS Marais Nature Reserve should be further investigated, as well as its implications for the use of the ITS region as a molecular marker.

\section{Acknowledgements}

The author wished to thank the Flemish Inter-University Council - University Development Cooperation (VLIR-UOS) and the Technology and Human Resources for Industry Programme (THRIP) for funding of the current project.

\section{Competing interests}

The authors declare that they have no financial or personal relationships that may have inappropriately influenced them in writing this article.

\section{Authors' contributions}

I.N. contributed towards the investigation and writing the original draft. R.K. contributed to the formal analysis, writing, reviewing and editing of the manuscript. A.P.M. was responsible for conceptualisation, methodology, fomal analysis, writing, reviewing and editing of the manuscript as well as supervision of the study and funding acquisition.

\section{Ethical considerations}

This article followed all ethical standards for research without direct contact with human or animal subjects.

\section{Funding information}

The authors would like to thank the Flemish Inter-University Council - University Development Cooperation (VLIR-UOS) and the Technology and Human Resources for Industry Programme (THRIP) for funding of the current project.

\section{Data availability}

The authors confirm that the data supporting the findings of this study are available within the article. 


\section{Disclaimer}

The views and opinions expressed in this article are those of the authors and do not necessarily reflect the official policy or position of any affiliated agency of the authors.

\section{References}

Abate, B.A., Malan, A.P., Tiedt, L.R., Wingfield, M.J., Slippers, B. \& Hurley, B.P., 2016 'Steinernema fabii n. sp. (Rhabditidae: Steinernematidae), a new species of entomopathogenic nematodes from South Africa', Nematology 18, 235-255. https://doi.org/10.1163/15685411-00002956

Abate, B.A., Slippers, B., Wingfield, M.J., Malan, A.P. \& Hurley, B.P., 2018, 'Diversity of entomopathogenic nematodes and their symbiotic bacteria in South African plantations and indigenous forests', Nematology 20, 335-317. https://doi. org/10.1163/15685411-00003144

Bedding, R.A., 1990, 'Logistics and strategies for introducing entomopathogenic nematode technology in developing countries', in R. Gaugler \& H.K. Kaya (eds.), Entomopathogenic nematodes in biological control, pp. 233-248, CRC Press, Boca Raton, FL.

Bedding, R.A. \& Akhurst, R.J., 1975, 'A simple technique for the detection of insect parasitic rhabditid nematodes in soil', Nematologica 21, 109-110. https://doi. org/10.1163/187529275X00419

Burnell, A.M. \& Stock S.P., 2000, 'Heterorhabditis, Steinernema and their bacteria symbionts - Lethal pathogens of insects', Nematology 2(1), 31-42. https://doi. org/10.1163/156854100508872

De Waal, J.Y., Malan A.P., Levings, J. \& Addison, M.F., 2010, 'Key elements in the successful control of diapausing codling moth, Cydia pomonella (L.) (Lepidoptera: Tortricidae) in fruit bins with a South African isolate of Heterorhabditis zealandica (Rortricidae) in fruit bins with a South African isolate of Heterorhabditis zealandica (Rhabditida: Heterorhabditidae)', Biocontrol Science

De Waal, J.Y., Malan, A.P. \& Addison, M.F., 2011, 'Efficacy of entomopathogenic nematodes (Rhabditida: Heterorhabditidae and Steinernematidae) against codling moth, Cydia pomonella (Lepidoptera: Tortricidae) in temperate regions', codling moth, Cydia pomonella (Lepidoptera: Tortricidae) in temperate regions, Biocontrol Science and
3157.2011.607922

Dlamini, T.M., Allsopp, E. \& Malan, A.P., 2019, 'Efficacy of entomopathogenic nematodes against western flower thrips, Frankliniella occidentalis (Thysanoptera: Thripidae), under laboratory conditions', African Entomology 27(2), 322-335. Thripidae), under laboratory conditions,
https://doi.org/10.4001/003.027.0322

Esler, K.J., Pierce, S.M. \& De Villiers, C., 2014, Fynbos - Ecology and management, Briza Publications, Pretoria.

Grewal, P.S., Ehlers, R. \& Shapiro-llan, D.I., 2006, Nematodes as biocontrol agents, $\mathrm{CABI}$, Wallingford.

Griffin, C.T., Downes, M.J. \& Block, W., 1990, 'Tests of Antarctic soils for insect parasitic nematodes', Antarctic Science 2, 221-222. https://doi.org/10.1017/ S095410209000030X

Hatting, J., Stock, P.S. \& Hazir, S., 2009, 'Diversity and distribution of entomopathogenic nematodes (Steinernematidae, Heterorhabditidae) in South Africa', Journal of Invertebrate Pathology 102, 120-128. https://doi.org/10.1016/j.jip.2009.07.003

Hatting, J.L. \& Malan, A.P., 2017, 'Status of entomopathogenic nematodes in integrated pest management strategies in South Africa', in M.M.M. Abd-Elgawad, T.H. Askary \& J. Coupland (eds.), Biocontrol agents: Entomopathogenic and slug parasitic nematodes, pp. 409-428, CABI, Wallington.

Hominick, W.M., 2002, 'Biogeography', in R. Gaugler (ed.), Entomopathogenic nematology, pp. 115-143, CABI Publishing, Wallingford.

Katumanyane, A., Ferreira, T. \& Malan, A.P., 2018, 'Bradysia species (Diptera: Sciaridae) as pests of covered crops, with special reference to biological contro using entomopathogenic nematodes', African Entomology 26(1), 1-13. https:// doi.org/10.4001/003.026.0001

Katumanyane, A., Malan, A.P., Tiedt, L.R \& Hurley, B.P., 2020, 'Steinernema bertusi $\mathrm{n}$ sp. (Rhabditida: Steinernematidae), a new entomopathogenic nematode from South Africa'. Nematology 22, 343-360. https://doi.org/10.1163/1568541100003309

Kaya, H.K. \& Gaugler, R., 1993, 'Entomopathogenic nematodes', Annual Review of Entomology 38, 181-206. https://doi.org/10.1146/annurev.en.38.010193.001145

Kaya, H.K. \& Stock, S.P., 1997, 'Techniques in insect nematology', in L. Lacey (ed.), Manual of techniques in insect pathology, pp. 281-324, Academic Press, London.
Malan, A.P. \& Hatting, J., 2015, 'Entomopathogenic nematode exploitation: case studies in laboratory and field applications from South Africa', in R. Campos-Herrera (ed.), Sustainability in plant and crop protection: Ecology and applied technologies for sustainable plant and crop protection, pp 475-506. Cham, Springer.

Malan, A.P., Knoetze, R. \& Moore, S.D., 2011, 'Isolation and identification of entomopathogenic nematodes from citrus orchards and their biocontrol potential against false codling moth', Journal of Invertebrate Pathology 108, 115-125. https://doi.org/10.1016/j.jip.2011.07.006

Malan, A.P., Nguyen, K.B. \& Addison, M.F., 2006, 'Entomopathogenic nematodes (Steinernematidae and Heterorhabditidae) from the southwestern parts of South Africa', African Plant Protection 12, 65-69.

Malan, A.P., Nguyen, K.B., De Waal J.Y. \& Tiedt, L., 2008, 'Heterorhabditis safricana n. sp. (Rhabditida: Heterorhabditidae), a new entomopathogenic nematode from South Africa', Nematology 10, 381-396. https://doi.org/10.1163/156854108783900258

Malan, A.P., Tiedt, T.R. \& Knoetze, R., 2016, 'A new entomopathogenic nematode, Steinernema nguyeni from South Africa', Nematology 18, 571-590. https://doi org/10.1163/15685411-00002978

Mucina, L. \& Rutherford, M.C., 2006, The vegetation of South Africa, Lesotho and Swaziland, Strelitzia 19, South African National Biodiversity Institute, Pretoria.

Nguyen, K.B., 2007, 'Methodology, morphology and identification', in K.B. Nguyen \& D.J. Hunt (eds). Entomopathogenic nematodes: Systematics, phylogeny and bacterial symbionts, pp. 59-119, Leiden, Brill.

Nguyen, K.B., Malan, A.P. \& Gozel, U., 2006, 'Steinernema khoisanae sp. n. (Rhabditida: Steinernematidae), a new entomopathogenic nematode from South Africa', Nematology 8, 157-175. https://doi.org/10.1163/156854106777998728

Nguyen, K.B., Maruniak J. \& Adams, B.J., 2001, 'Diagnostic and phylogenetic utility of the rDNA internal transcribed spacer sequences of Steinernema', Journal of Nematology 33(2-3), 73-82.

Nguyen, K.B. \&. Smart, G.C., Jr., 1990, 'Steinernema scapterisci n. sp. (Rhabditida: Steinernematidae)', Journal of Nematology 22, 187-199.

Nguyen, K.B. \& Smart, G.C., Jr., 1996, 'Identification of entomopathogenic nematodes in the Steinernematidae and Heterorhabditidae (Nemata: Rhabditida)', Journal of Nematology 28(3), 286-300.

Půža, V., Chundelová, D., Nemut', J., Žurovcová, M. \& Mráček, Z., 2015, 'Intraindividual variability of ITS regions in entomopathogenic nematodes (Steinernematidae: Nematoda): Implications for their taxonomy', BioControl 60, 547-554. https://doi.org/10.1007/s10526-015-9664-5

Shapiro-llan, D.I., Gouge, D.H. \& Koppenhofer, A.M., 2002, 'Factors affecting commercial success: Case studies in cotton, turf and citrus', in R. Gaugler (ed.), Entomopathogenic nematology, pp. 333-356, CABI, Wallingford.

Steyn, V.M., Malan A.P. \& Addison, A., 2020, 'Efficacy of entomopathogens against Thaumatotibia leucotreta (Lepidoptera: Tortricidae) under laboratory conditions' Entomologia Experimentalis et Applicata 168, 499-461. https://doi.org/10.1111/ eea.13044

Steyn, W.P., Knoetze, R., Tiedt T.R. \& Malan, A.P., 2017a, 'Steinernema litchi n. sp. (Rhabditida: Steinernematidae), a new entomopathogenic nematode from South Africa', Nematology 19, 1157-1177. https://doi.org/10.1163/15685411 00003116

Steyn, W.P., Malan, A.P., Daneel, M.S. \& Slabbert, R.M. 2017b, 'Entomopathogenic nematodes from north-eastern South Africa and their virulence against the false codling moth, Thaumatotibia leucotreta (Lepidoptera: Tortricidae)', Biocontrol Science and Technology 27(11), 1265-1278. https://doi.org/10.1080/09583157.2 017.1391174

Stock, S.P. \& Kaya, H.K., 1996, 'A multivariate analysis of morphometric characters of Heterorhabditis species (Nematoda: Heterorhabditidae) and the role of morphometrics in the taxonomy of species of the genus', Journal of Parasitology 82 , 806-813.

Stock, S.P., Pryor B.M. \& Kaya, H.K., 1999, 'Distribution of entomopathogenic nematodes (Steinernematidae and Heterorhabditidae) in natural habitats in California', Biodiversity \& Conservation 8(4), 535-549.

Van Zyl, C. \& Malan, A.P., 2015, 'Optimisation of inoculation techniques for in vivo mass culture of entomopathogenic nematodes through nematode and insect host manipulation', African Entomology 24, 405-416. https://doi. org/10.4001/003.022.0221

Vrain, T.C., Wakarchuck, D.A., Lèvesque A.C. \& Hamilton R.I., 1992, 'Intraspecific rDNA restriction fragment length polymorphism in the Xiphinema americanum group', Fundamental and Applied Nematology 15, 563-573.

Woodring, J.L. \& Kaya, H.K., 1988, 'Steinernematid and heterorhabditid nematodes: A handbook of techniques', Southern Cooperative Series Bulletin 331, Arkansas Agricultural Experimental Station, Fayetteville, Arkansas, 30 pp. 